\title{
Stabilisation of Silty Soil by Pond Ash, Rice Husk Ash, Cement and Phosphogypsum
}

\author{
Bharat Bhushan Jindal ${ }^{1}$, Nirpinder Jain ${ }^{2}$ \\ ${ }^{1}$ Associate Professor, Department of Civil Engineering, MM University Sadopur Ambala, India \\ ${ }^{1,2}$ Research Scholar, IK Gujral Punjab Technical University, Kapurthala, Punjab, India \\ ('bbjal1972@hotmail.com)
}

\begin{abstract}
Utilization of bulk quantity of Industrial waste produced globally is a serious concern in today's era. Nearly $75 \%$ of India's total installed power generation is from thermal power station which is $90 \%$ coal based, producing tremendous quantity of fly ash as well as pond ash, which requires a large area to dispose off. The bulk utilization of fly ash is only possible by the way of geotechnical application such as embankment construction, backfill material and sub base material. Phosphogypsum is another kind of waste Calcium Sulphate produced by fertilizer plants during production of phosphoric acid, a major constituent of many fertilizers. Phosphogypsum contains a variety of impurities which may contaminate the ground soil and ground water if not properly utilized. This paper discusses the investigated results of compaction tests, CBR tests conducted on test specimens of soil with varying percentage of pond ash, rice hush ash, cement and phosphogypsum. The test specimens were cured for 7 days, 14 days and 28 days. It was found that CBR value of soil increases significantly on addition of these waste materials, which encourages the bulk utilization of these waste materials in stabilization of soils having low CBR values.
\end{abstract}

Keywords - Pond ash, fly ash, rice husk ash, phosphogypsum, silty soil

\section{INTRODUCTION}

Soil can be defined as the upper layer of the earth consisting of air, water and solid particles is generally produced by disintegration of rocks. Abundantly available soil is the cheapest construction material in most of the regions of the world. The properties of the soil vary from point to point and place to place. Cohesive soil causes great engineering problems due to its poor strength, high compressibility and low permeability. It covers large and extensively located areas of India and also many parts of the world. Silty soil extends in large stretches and construction of pavements and other structures on such type of soils is a great problem. To set right these problems it is very much necessary to treat these soils. There are so many methods for the treatment of these soils. Some of them are very costly and some are very tedious. But the treatment of soft clayey soils with fly ash, Rice husk ash, Phasphogypsum along with small quantity of cement is very simple, economical and pollution controlling.

\section{NECESSITY OF STRENGTHENING THE SOIL}

In the third world countries, the need for locally manufactures construction material is increasing due to greater demands for new roads and housing units created by a growing population. Over the years, the availability of conventional material has not been sufficient to meet the demand of growing population. However, development of a large network of roads by traditional means and techniques require heavy financial investments. So, it becomes need of the hour to find alternative materials, preferably locally available low grade ones for use in pavement construction, which results in sizeable economy without compromising with the engineering performance of structure.

Several methods of soil improvement using Pozzolanic materials have been developed and used successfully in practice. It has been applied in a variety of civil engineering works, like in the construction of base courses where good materials are not economically available; for reducing the permeability and compressibility of soils in hydraulic and foundation works; for stabilisation of slopes, embankments and excavations. A considerable amount of research concerning stabilisation of soil with additives such as cement, lime, lime - fly ash and salt, bitumen and polymers is available in the literature. But soil stabilization with cement, rice husk ash (RHA) and phosphogypsum is a relatively a new method and very few literature is available related to this topic. 


\section{METHODS TO IMPROVE THE PROPERTIES OF THE SOIL}

Soil improvement may be broadly defined as the alteration or preservation of one or more soil properties to improve the engineering characteristics and performance of a soil which may broadly fall under three categories, viz., removal of undesirable materials, control of groundwater, strengthening the geological materials and reclaimed materials. Silty soil having small size particles and very large water retention capacity is generally considered as weak soil. It undergoes considerable settlement due to its swelling and shrinkage characteristics. It is a weak material in engineering properties like shear strength, bearing capacity, permeability and compressibility etc. The alteration of soil properties to meet specific engineering requirements is known as soil stabilisation. A change of soil texture takes place on lime stabilisation. (1) Expensive soils can be potentially stabilized by cation exchange using fly ash. (2) Furguson and Leverson (1999) pointed out that clayey soils have soaked CBR values from $1.5 \%$ to $5 \%$, which provided very little support to the pavement structure. (3) The properties of a soil may be improved by following ways, among which are.

1. Mechanical stabilisation, compaction etc.

2. Chemical stabilisation

3. Drainage method

4. Consolidation methods

5. Grouting of the sub grade

6. Vibration method

7. Thermal treatment

8. Electro-osmosis

9. Soil reinforcement

10. Geo synthetics

Jha and Gill (2006) concluded that rice husk ash stabilized soil along with controlled lime content showed average strength retention in the range of 59\% to 69\%. (4) Kumar et al. (2007) observed increase in optimum water content from $28 \%$ to $38 \%$ with percentage increased of fly ash as $5 \%$ to $20 \%$ and lime $2 \%$ to $10 \%$. Misra et al (1998) states the long term strength gain is expected for class C fly ash stabilized soils. (6)

\section{OBJECTIVES OF STUDY}

The aim of this exercise is to monitor the effect of Pond ash, Rice husk ash, Phasphogypsum and cement on silty soils.

\section{EXPERIMENTAL WORK}

An experimental program was planned to study the effect of pond ash, rice husk ash, Phasphogypsum and cement on locally available soil.

\section{Soil}

The soil used in the investigation is local soil of Ludhiana. According to Indian Standard of Soil Classification, the soil is of low compressibility Silt.

\section{Pond Ash}

Pond ash used in present study is collected from Guru Hargobind Singh Thermal Power Station, Lehra Mohhabat Distt. Bathinda.

\section{Rice Husk Ash}

Rice husk ash was obtained from N K Enterprises, Singhania House, Jharsuguda, and Orissa, INDIA.

\section{Phasphogypsum}

Phasphogypsum is another kind of waste Calcium Sulphate produced by fertilizer plants during production of phosphoric acid, a major constituent of many fertilizers. Phasphogypsum was obtained from NFL plant, Nangal, Punjab, India.

\section{Portland Pozzolana Cement (Ppc)}

The PPC cement was obtained from market of Jaypee brand.

\section{Mixing Proportions}

Soil, Pond ash, RHA, Cement \& Phasphogypsum is to be mixed thoroughly to have a uniform mixture. 
IOSR Journal of Mechanical and Civil Engineering (IOSR-JMCE)

e-ISSN: 2278-1684, p-ISSN: 2320-334X

These are to be mixed in proportions given below in Table 1

Table I Mixed In Proportions

\begin{tabular}{|c|c|c|c|c|c|c|}
\hline $\begin{array}{c}\text { S. } \\
\text { NO }\end{array}$ & $\begin{array}{c}\text { NAME OF } \\
\text { PROPORTION }\end{array}$ & $\begin{array}{c}\text { SOIL } \\
(\%)\end{array}$ & $\begin{array}{c}\text { POND } \\
\text { ASH } \\
(\%)\end{array}$ & $\begin{array}{c}\text { RICE HUSK } \\
\text { ASH } \\
(\%)\end{array}$ & $\begin{array}{c}\text { CEMENT } \\
(\%)\end{array}$ & $\begin{array}{c}\text { PHASPHOGYPSUM } \\
(\%)\end{array}$ \\
\hline 1 & $\mathrm{~S}_{100} \mathrm{PA}_{0} \mathrm{R}_{0} \mathrm{C}_{0} \mathrm{Ph}_{0}$ & 100 & 0 & 0 & 0 & 0 \\
\hline 2 & $\mathrm{~S}_{57} \mathrm{PA}_{20} \mathrm{R}_{20} \mathrm{C}_{3} \mathrm{Ph}_{0}$ & 57 & 20 & 20 & 3 & 0 \\
\hline 3 & $\mathrm{~S}_{57} \mathrm{PA}_{20} \mathrm{R}_{20} \mathrm{C}_{3} \mathrm{Ph}_{0.5}$ & 57 & 20 & 20 & 3 & 0.5 \\
\hline
\end{tabular}

CBR tests were performed on the samples by varying curing period under soaked conditions.

\section{RESULTS \& DISCUSSIONS}

1. Effect of curing period on CBR value under soaked condition is shown in Fig. 1.

2. Effect of curing period on CBR value under soaked condition with $0.5 \%$ Phasphogypsum is shown in Fig. 2.

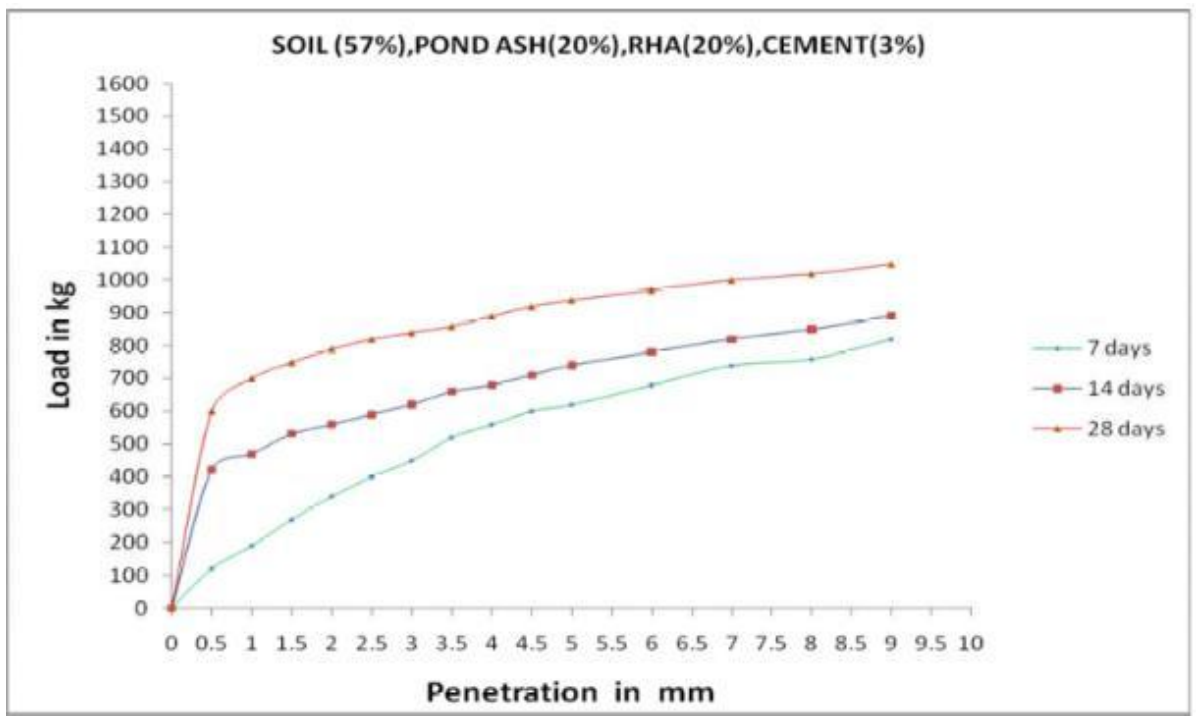

Figure 1: Effect of curing period on CBR Value (soaked)

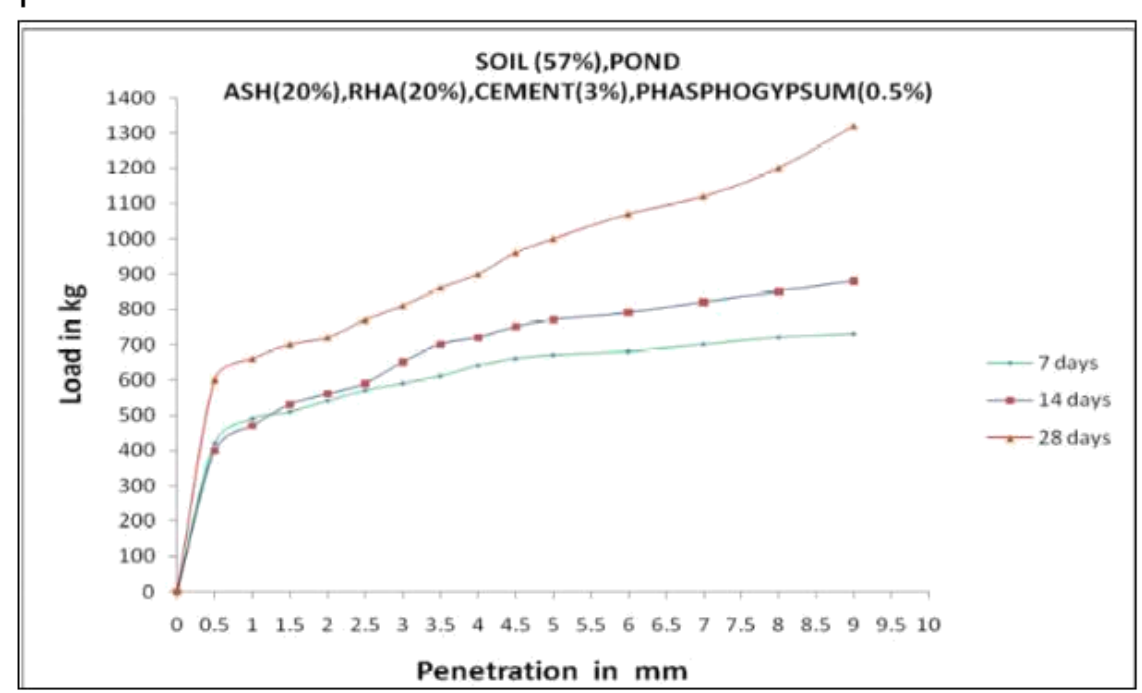

Fig 2: Effect of Curing Period on CBR Value (Soaked) With $0.5 \%$ Phasphogypsum 
3. A significant improve in CBR value of silty soil on addition of pond ash, RHA, cement and Phasphogypsum is observed which is illustrated in Table II

Table II A significant improve in CBR value of silty soil on addition of pond ash, RHA, cement and Phasphogypsum

\begin{tabular}{|c|c|c|c|c|}
\hline Sr. No. & Mix & $\begin{array}{l}\text { Curing } \\
\text { Period }\end{array}$ & CBR\%(Soaked) & $\begin{array}{l}\text { \% age increase in } \\
\text { CBR\%(soaked) }\end{array}$ \\
\hline 1 & 100:0:0:0:0 & & 4.2 & -- \\
\hline \multirow[t]{3}{*}{2} & \multirow[t]{3}{*}{$57: 20: 20: 3: 0$} & 7 days & 30.4 & 752 \\
\hline & & 14 days & 35.8 & 752 \\
\hline & & 28 days & 45.4 & 980 \\
\hline \multirow[t]{3}{*}{3} & \multirow[t]{3}{*}{$57: 20: 20: 3: 0.5$} & 7 days & 32.4 & 672 \\
\hline & & 14 days & 37.26 & 787 \\
\hline & & 28 days & 48.6 & 1057 \\
\hline
\end{tabular}

\section{CONCLUSION}

[1] The CBR value (soaked) of virgin soil increased by $624 \%, 752 \%$ and $980 \%$ on addition of $20 \%$ pond ash, $20 \%$ RHA and $3 \%$ cement for 7 days, 14 days and 28 days curing of samples respectively.

[2] The CBR value (soaked) of virgin soil increased by $672 \%, 787 \%$ and $1057 \%$ on addition of $20 \%$ pond ash, $20 \%$ RHA, $3 \%$ cement and $0.5 \%$ phasphogypsum for 7 days, 14 days and 28 days curing of samples respectively.

\section{FUTURE SCOPE OF STUDY}

The effect of different \%ages of pond ash and rice husk ash can be studied.

The effect of longer curing period may be studied.

The effect of pond ash and RHA can also be studied for clayey type of soils.

\section{REFERENCES}

[1] Chen, F.H. (1975) Foundation on expensive soils, Elsevier Sciences, Amesterdam, The Netherland.

[2] Cokca, E. (2001), "Use of Class C fly ash for the stabilisation of an expensive soil." J.Geoenviron.Eng.,127(7),568-573.

[3] Ferguson, G., \& Leverson.S.M.(1999) "Soil and pavement base stabilisation with self cementing coal fly ash." American Coal Association, Alexentria,V.A.

[4] Jha J.N., Gill K.S., "Effect of Rice Husk Ash On Lime Stabilisation of Soil”, Institution of Engineers, India 2006

[5] Kumar Arvind, Walia B.S., Bajaj Asheet (2007) "Influence of Fly Ash, Lime and Polyester fibres on compaction and strength properties of expensive soils" Journal of Materials in civil engg. ASCE Vol. 19.

[6] Mishra A (1998) "Stabilisation characteristics of clay using Class C fly ash." Transport Research Board Record 1611, Transport Research Board, 46-54. 